\title{
Investigating the Difference in Policy Responses to the 2004 and 2005 Hurricane Seasons and Homeowner Insurance Crises in Florida and Louisiana
}

\author{
Emanuel Ubert \\ University of Wisconsin-Madison
}

\begin{abstract}
In 2004 and 2005, a series of hurricanes caused record homeowner insurance losses in Florida and Louisiana. Despite comparably sized losses, the two states responded differently to these shocks. Florida expanded state subsidized homeowner insurance, breaking from a free market response, whereas Louisiana actively promoted private market supply. Comparing the two policy processes reveals that the politics and transformation of homeowner insurance evoked by extreme weather events depend on how concentrated the hurricane impact is and whether it effectively mobilizes homeowners into electoral politics. The broader distribution of losses in Florida prompted homeowners to exert sufficient electoral pressure to influence policy responses, fostering political dynamics emphasized by interest group theories of policy, and a break from the market. The more concentrated hurricane impact in Louisiana blocked homeowners from doing the same, leaving Louisiana's policymakers free to draw on the institutionalized free-market logic to guide their response to hurricane damages and producing trajectories expected by structural-class theories. The findings highlight the contingency of different approaches to the politics of markets and policy, suggesting that the dynamics proposed by the two theories depend on the distribution and political impact of the problems and shocks involved.
\end{abstract}

\author{
Contact Information: \\ Emanuel Ubert \\ Department of Sociology \\ University of Wisconsin-Madison \\ 8128 William H. Sewell Social Science Building \\ 1180 Observatory Drive \\ Madison, WI 53703 \\ E-Mail: eubert@wisc.edu
}




\section{Introduction}

Extreme weather events are a growing source of economic losses. Today there exists "high confidence, based on high agreement and medium evidence, that economic losses from weatherand climate-related disasters have increased" (IPCC, 2012, p. 268). Losses from Atlantic hurricanes in particular have grown over the last three decades (Elsner et al., 2008). Eight out of the ten largest U.S. catastrophes have been hurricanes, six of which have occurred since the early 2000s (Insurance Information Institute, 2014). Hurricane-related losses are also predicted to grow in the future (Holland and Webster, 2007; IPCC, 2012). Florida and Louisiana are the two states with the greatest hurricane exposure. In the record 2004 and 2005 hurricane seasons, the two states suffered the greatest total damage and insured losses in the U.S. Florida incurred an estimated \$19 billion insurance loss from four named hurricanes in 2004 and an estimated \$12 billion loss from four storms in 2005. Louisiana incurred \$29 billion in estimated losses from two hurricanes in 2005. Despite these comparable costs, the two states pursued different insurance policies in response to the 2004 and 2005 hurricane seasons: Florida expanded the public provision of homeowner insurance while Louisiana deepened private insurance provision. This paper explains why the two states responded differently and argues that the politics of insurance is more generally contingent on the level of concentration of unexpected extreme weather events.

Homeowner insurance plays a critical role in insulating the wider economy from extreme weather cost shocks. Uninsured damages from natural disasters tend to permanently reduce economic activity in the jurisdiction in which they occur. Insured damages create only temporary GDP shortfalls (von Peter et al., 2012). Homeowner insurance protects against wind damage from hurricanes, which, besides flooding, has the greatest economic impact on the value of residential housing structures. ${ }^{1}$ In 2007, construction, real estate, and rental activities constituted $24 \%$ and $14 \%$ of state GDP in Florida and Louisiana respectively (Bureau of Economic Analysis, 2016). The large weight of the housing sector in state GDP means that uninsured hurricane reductions of housing values have the capacity to significantly impact a state's overall economic performance and stability (Liu and Brennan, 2008).

Two distinct but interrelated types of organizations provide homeowner insurance coverage in Florida and Louisiana: private profit-maximizing or voluntary insurers, and statecoordinated or residual insurance corporations. While relying on voluntary insurers to provide 
the majority of homeowner insurance, Florida and Louisiana each launched their own integrated residual insurance corporation -Florida Citizens Property Insurance Corporation ("Florida Citizens") and Louisiana Citizens Property Insurance Corporation (“Louisiana Citizens") — in 2003 and 2004 respectively. Residual insurance programs differ from private insurance in two critical aspects: price and supply levels are generally not market determined and costs from residual exposure are spread over a larger share of the population.

Florida and Louisiana commissioned residual programs to exclusively offer "insurance-oflast-resort" to homeowners who could not obtain coverage from private insurers (Insurance Information Institute, 2015). Both residual insurance organizations' policy terms and rates were originally set so as to render them uncompetitive with voluntary insurers. In that sense, the residual insurance price and supply levels in both states are politically determined rather than by market considerations.

Besides being non-market entities, residual insurance also distributes the costs of uncovered claims to a broader section of the population than private insurance. In contrast to their voluntary counterparts, Florida Citizens and Louisiana Citizens do not accumulate any capital reserves; they rely on retained earnings to pay out insurance claims. When residual insurers incur unexpectedly large claims, as they did following the 2004 and 2005 hurricane seasons, they fall back on direct government bailouts or on the bond market to pay their policy holders. In the latter case, state governments, on the residual insurer's behalf, levy special "assessments" or surcharges on all voluntary homeowner insurance policyholders in the state to pay off the bonds. All homeowner insurance policyholders and, in case of direct bailouts, state taxpayers back residual insurance risk and pay for its extraordinary costs. ${ }^{2}$ In that sense, residual insurance extracts cross-subsidies from all homeowner insurance policyholders and taxpayers. Greater residual insurance coverage therefore shifts hurricane risks and costs to a larger share of a state's population.

In response to the 2004 and 2005 record hurricane disruptions and the subsequent 2006 state elections, Florida's legislators adopted laws designed to systematically expand the provision of residual homeowner insurance. Louisiana, in contrast, passed laws designed to support and expand the provision of private homeowner insurance leading up to and following its own state elections in 2007. In light of a broader shift away from public insurance in the rest of the U.S. economy (Hacker, 2008), and given the comparable free-market and anti-government 
ideologies in the two states, Florida's expansion of state-coordinated homeowner insurance provision is puzzling. Following the record 2004 and 2005 hurricane seasons, why did Florida turn to the state to become the primary provider of homeowner insurance in high hurricane-risk regions, while Louisiana turned to the private insurance market?

The paper uses two theories, interest group theory ("IGT") and structural-class theory ("SCT"), to guide the comparative tracing of the policy processes that link the 2004 and 2005 hurricane cost shocks to the different legislative responses in Florida and Louisiana in 2007. The paper argues that the type of policy process and outcome in response to unexpected record hurricane shocks depends on the timing and distribution of the hurricanes' property damages and the timely presence of political openings.

In Florida, the worst destruction from eight hurricanes over the course of two years affected a mostly White majority of the population. That majority managed to publicly frame growing insurance premiums as a problem of market fairness and to delegitimize private insurance provision. The resulting politicization of homeowner insurance affordability during the 2006 state election pressured legislators to reject taken-for-granted free-market solutions to the insurance affordability crisis. In 2007, the incoming state government instead adopted the antimarket policies demanded by homeowner groups.

In Louisiana, two geographically concentrated hurricane shocks within one month of each other most greatly affected a relatively disenfranchised segment of the population that could not politically mobilize as effectively as homeowners in Florida. Concerned about the wider economic effects of private insurance market disruptions, lawmakers instead continued to pursue their already existing policy of deepening and expanding the private homeowner insurance market and limiting state involvement in the provision of insurance before and after the state election in 2007. They understood the adopted free-market policies to be the best means not only to reduce insurance prices but also to stabilize the wider economic system.

In Louisiana, the narrower distribution of hurricane losses triggered a policy process best characterized by SCT. In Florida, the worst hurricane damages and subsequent homeowner insurance affordability and availability problems triggered the kind of policy process and outcome theorized by IGT. The case-specific findings suggest that a shift from market to greater public provision of insurance in response to extreme weather events more generally, and the 
policy process proposed by IGT as opposed to SCT, depend on a greater distribution of costs from these shocks at the conjunction of political opportunity.

The argument proceeds as follows: First, the paper outlines the policy processes and outcomes theorized by IGT and SCT. After describing the methods and data used, the paper employs the two theories and key differences between the two states to guide the tracing of the policy responses to the 2004 and 2005 hurricane shocks in the two states. The paper concludes by discussing the findings, making a general claim based on the case-specific findings, and briefly outlining future directions of research to refine and test that claim.

\section{Theory}

No existing studies unequivocally explain the different insurance policy outcomes in Florida or Louisiana. Insurance economists have carefully described market and regulatory adjustments to the 2004 and 2005 hurricane shocks in the Gulf of Mexico (see, for example, Grace and Klein, 2009; Klein, 2007, 2009), but have not theorized the factors and processes responsible for the different state responses. SCT and IGT have been successfully employed to explain different policy processes and outcomes in the substantively close field of worker-compensation insurance, including the adoption of state as opposed to private insurance systems (Fishback and Kantor, 1996, 1997; Pavalko, 1989). Similar to homeowner insurance, worker-compensation insurance can have significant economic consequences for the insured as well as the wider economy. Additionally, while private firms have historically provided worker-compensation insurance in most states, some state governments adopted state-backed programs that, similarly to residual homeowner insurance in Florida and Louisiana, did not exclusively rely on market forces. The findings in the worker-compensation studies and the associated theoretical insights by SCT and IGT help identify what kind of insurance policy processes and outcomes one might expect in our two states and thereby guide the comparative process tracing analysis in section 4. The following section outlines the key theoretical claims made by SCT and IGT regarding policy processes and outcomes, summarizes their relevance to the adoption of worker-compensation insurance systems, and, by extension, to homeowner insurance policy responses to unexpected record hurricane disruptions in Florida and Louisiana.

\subsection{Structural-Class Theory (SCT)}


SCT explanations of policy outcomes (Offe, 1984; Poulantzas, 1973; Pzeworski, 1985; Therborn, 1978) focus on how capital accumulation and the resulting social relations shape actors' political preferences, political opportunity spaces, and the role of the state in harmoniously reproducing capitalist relations. Under stable political-economic conditions, hegemonic material and social practices tend to sanction ideologies that filter out individuals' beliefs and values that challenge the reproduction of existing class relations. Many of those practices are directly or indirectly sanctioned by the state. Crises that disrupt the smooth reproduction of the status quo open up the potential for struggles over the structure of the existing political-economic system itself. Faced with such crises, and in order to preempt challenges to the status quo, the semi-autonomous capitalist state intervenes on behalf (but not on behest) of the typically fragmented capitalist class and adopts policies designed to restore economic stability (Offe, 1984).

SCT policy processes played a central role in the timing of the adoption of workercompensation insurance systems in the U.S. According to Pavalko (1989, p. 593), "macroindicators that shaped politician's perceptions of the need for workman's compensation, the range of possible decisions, and the consequences of their actions and inactions" were more relevant to the relative timing of state adoption of worker-compensation insurance programs than interest group competition, existing bureaucratic capacities of the state, or electoral politics (pp. 606-608). The adoption of "workmen's compensation went beyond the specific interests of employers or workers to remove a threat to the long-term accumulation of capital" (p. 600). State economies with high levels of mechanization of work processes had the most to lose from growing work-accident costs and were consequently the fastest to adopt worker compensation insurance (p. 609).

Similar to the case of worker-compensation insurance, SCT would expect state actors as opposed to competing interest groups to take the lead in changing homeowner insurance policy when it becomes clear that hurricane disruptions threaten the stability of the wider economy. In ideologically pro-market and anti-statist Florida and Louisiana, such policies should generally have a pro-market bias in the sense of reducing regulatory restrictions of private insurance markets and the strengthening of the private as opposed to the public provision of homeowner insurance. 


\subsection{Interest Group Theory (IGT)}

IGT explanations of policy outcomes (Dahl, 1961; Lowi, 1979; Meier, 1988; Peltzman, 1976) focus on interest group competition and influence over government decision-making. Theories in this tradition generally assume that semi-autonomous legislators make political decisions to maximize their own political support. Policy outcomes therefore reflect the interests of those groups that can offer most political support to policymakers. Policymakers consequently act on behest and not on behalf of the most influential groups. The perspective takes as given the democratic environment that structures political group competition and incentives. Efforts to systematically transform capitalist dynamics and class relations lay outside the theory.

Regarding the adoption of worker-compensation insurance, labor, agricultural and insurance groups all supported the establishment of worker insurance systems to avoid the looming cost crises of the existing court-based negligence liability system (Fishback and Kantor, 1997). No agreement existed, however, on whether those systems should primarily be market- or state-coordinated. Insurance and agricultural groups actively opposed the establishment of exclusively state-funded insurance programs and successfully used their greater political clout to persuade state legislatures to implement private insurance systems in most states. Only politically strong labor unions or broader progressive coalitions managed to overcome agricultural and insurance group influence and persuade a handful of state governments to adopt state-run insurance programs (Fishback and Kantor, 1996, p. 811). Political contests between opposing interest groups characterized the policy process and determined which type of worker compensation insurance system states adopted.

Unexpectedly large hurricane shocks impose different costs on different socio-economic groups. Similar to the conflicts surrounding the type of worker insurance program adoption, IGT would expect political competition among the most affected groups to characterize the policy process generating the observed policy outcomes in Florida and Louisiana. The different outcomes ultimately would reflect the different political demands of the most resourceful and politically effective groups in each state. Contrary to SCT, the policy process theorized by IGT is more politicized and its outcomes are not necessarily biased towards the reproduction of the existing capitalist economic order. In the context of contemporary Florida and Louisiana, IGT would expect pro-market policy outcomes comparable to those predicted by SCT in case insurance companies and allied groups have relatively greater political influence (Meier, 1988). 
The adoption of policies designed to expand regulation or other means to constrain or even replace private with state-coordinated homeowner insurance would be more likely if consumer and their allied groups more effectively organized and lobbied state officials (also see Schneiberg and Bartley, 2001; Schneiberg and Soule, 2005).

\section{Methods and data}

In order to explain the shift from private to public insurance in Florida but not in Louisiana in 2007, the paper employs a comparative process tracing analysis of the homeowner insurance policy processes in the two states between 2005 and 2008. Process tracing leverages the theoretical insights of SCT and IGT to explain the policy outcomes in each of the two states. The complementary comparison of the two states further empirically guides the within-state process tracing, helps account for the difference in the policy outcomes, and allows for the contingent generalization of the case-specific explanations. This section elaborates these two complementary methods and outlines the data they draw on.

\subsection{Within-state policy process tracing}

Process tracing is a historical within-case-study method that seeks to identify the causal process linking independent with intervening and dependent variables (George and Bennett, 2005, p. 206). In our context, the dependent variables of interest are the homeowner insurance policy outcomes in Florida and Louisiana around 2007. The hurricane shocks of 2004 and 2005 constitute the key independent variables - the unexpected shocks to the insurance system. The identification of the process linking these two through relevant intervening events offers a better explanation for the observed policy outcomes than other methods. Unlike statistical approaches or an exclusive case-comparison, for example, process tracing can effectively test theories and inductively generate hypotheses in an environment marked by multiple, complex, and intertemporal interaction effects ${ }^{3}$ - the environment characterizing the political economy of homeowner insurance markets in Florida and Louisiana following the 2004 and 2005 record hurricanes.

Leveraging these advantages, the explanation of the insurance policy outcomes combines deductive and inductive approaches to within-state process tracing (Bennett and Checkel, 2015, pp. 7-8, Falleti and Mahoney, 2015, pp. 229-234; George and Bennet, 2005, pp. 217-218). To the 
extent to which SCT and IGT provide sufficiently concrete and observable expectations, they guide the historical qualitative delineation of the process that connects hurricane shocks and the insurance policy outcomes in Florida and Louisiana. More concretely, this involves tracing the reaction of state officials and key interest groups to the state-specific hurricane disruptions, to each other's actions, and how both affected homeowner insurance policies in the two states between 2005 and 2008. To the extent to which theoretical guidance from SCT and IGT are not sufficiently specified or unobservable, the analysis relies on inductively generated evidence to fill the gaps in the policy process.

\subsection{State comparison}

The study complements the within-state process tracing with a comparison of the two states' background conditions. Following a "logic-of-difference," the comparison eliminates shared background conditions as potential explanatory factors for the different insurance policy outcomes in 2007 (Falleti and Mahoney, 2015, pp. 225-226). The identification of those differences empirically focuses the process tracing analysis beyond the theoretical guidance from SCT and IGT. It also makes possible contingent generalizations about the conditions under which the different identified policy processes, and the theories that characterize them, explain insurance policy responses to extreme weather events. Practically, the comparative step in the analysis involves the identification of homeowner insurance-related structural and institutional differences between the two states and their incorporation into the process tracing exercise. Next, I briefly summarize the key differences between the two states.

Despite their location in the "deep South," comparable politically conservative, antigovernment and pro-market ideologies, market-coordinated economies, and similarly sized hurricane insurance losses in 2004 and 2005, the two states differ in some key dimensions with regards to homeowner insurance provision and hurricane shocks. Table 1 below lists the most relevant differences (and some similarities) between the two states around the time of the policy divergence (i.e. in 2007). 


\section{Table 1}

\section{Hurricane exposure \& coastal development}

\section{Florida Louisiana}

2004/2005 estimated insured hurricane damage, in \$mio

Total no. of hurricane landfalls, 2004/2005

Counties with at least $\$ 1 \mathrm{bn}$ in total damage

Share of total property damage

Share of total population

Share of Whites

Average population density per square mile

Median occupied house value, in $\$$

Average housing occupancy

Median per-capita income, in $\$$

Poverty rate

\begin{tabular}{|c|c|}
\hline 30,900 & 28,837 \\
\hline 8 & 2 \\
\hline 17 & 6 \\
\hline $94 \%$ & $69 \%$ \\
\hline $53 \%$ & $26 \%$ \\
\hline $82 \%$ & $69 \%$ \\
\hline 486 & 619 \\
\hline 201,700 & 172,400 \\
\hline $58 \%$ & $58 \%$ \\
\hline 27,561 & 23,069 \\
\hline $7 \%$ & $8 \%$ \\
\hline $2,458,600$ & 224,400 \\
\hline $79 \%$ & $35 \%$ \\
\hline $66 \%(43 \%)$ & $83.8 \%$ (56\%) \\
\hline $18 \%$ & $10 \%$ \\
\hline 6,402 & 1,218 \\
\hline 9,203 & 3,592 \\
\hline 2006 & 2007 \\
\hline No & Yes \\
\hline Republican & Republican \\
\hline No & No \\
\hline Republican & Democrat \\
\hline $3,239,218$ & 868,951 \\
\hline $1,841,321$ & 758,408 \\
\hline Yes & No \\
\hline Yes & No \\
\hline Yes & No \\
\hline
\end{tabular}

Insurance market

Value of residential insured coastal hurricane exposure, in \$mio

Coastal P\&C insurance exposure as percentage of total insurance, 2007

Top 10 (3) voluntary P\&C market share, 2007

Residual market share, 2007

Homeowner premiums written, 2007, in \$mio

Auto premiums written, 2007, in \$mio

\section{Politics}

State election

Gubernatorial party shift

Gubernatorial party, 2007

Majority shift in either legislative chamber during election

Legislative majority party, 2007

Real estate sector election contribution to legislature, in \$

Insurance sector election contribution to legislature, in \$

Homeowner insurance a major theme in state election

Post-election special legislative session addressing homeowner insurance issues

Criticism of voluntary homeowner insurance providers by governor (elect), 2007

Sources: American Community Survey 2005-2009, AIR Worldwide, Insurance Information Institute, followthemoney.org, Property Claims Services, SHELDUS.

Although the 2004 and 2005 hurricane seasons caused comparable insurance losses in both states, Florida's worst property damage was temporally, geographically and demographically more spread out than in Louisiana. In Florida, seventeen counties with approximately $50 \%$ of the state's total, though predominantly White, population each suffered more than $\$ 1$ billion in total property damages - more than $90 \%$ of the total damages created in both hurricane seasons. In Louisiana, only two hurricanes - hurricane Katrina and Rita - occurred within a month of each 
other in 2005 and caused more than $\$ 1$ billion in damages in only six parishes surrounding and including New Orleans. Compared to Florida, these most damaged counties contained only a quarter of the overall state population and were more densely populated, less affluent, and less White.

The two states also differed in terms of their property insurance market structures. Florida's property and casualty insurance market was less concentrated and significantly more exposed to coastal hurricane risk. Absent any hurricane shocks, Florida's considerably larger market size, including a larger lucrative auto insurance segment, make it more attractive for private insurers to operate in. Partly due to its small market size, Louisiana historically has had difficulties attracting voluntary insurers to the state. Based on these structural market characteristics, private insurers have, by default, more to lose from exiting Florida than Louisiana. At least nominally, regulators and legislators therefore had greater leverage over voluntary insurers in Florida than in Louisiana.

Politically, both states held state elections within two years of the 2005 hurricane season. While state congressional majorities remained unchanged in both states, in Louisiana, Republican Bobby Jindal succeeded Democratic Governor Blanco who did not seek reelection post hurricane Katrina. The real estate sector contributed relatively larger amounts of funding to the state congressional elections in Florida; it contributed roughly the same as the overall insurance sector in Louisiana. Finally, homeowner insurance availability and affordability issues received greater legislative attention in Florida than in Louisiana during the election and immediately after.

Above differences in hurricane damage distributions, property insurance market structures, and in electoral politics constitute state-specific factors that potentially condition policy processes in a way that accounts for Florida's but not Louisiana's shift to greater residual homeowner insurance provision in 2007. The process tracing analysis in section 4 therefore pays special attention to how these factors condition residential insurer, homeowner, regulator and key legislators' (inter)actions leading up to the policy divergence in 2007.

\subsection{Data and measures}

The comparative process tracing approach requires fine-grained measures of all the intervening events and the mechanisms that link them and the eventual policy outcomes in 2007: the initial 
size, timing, and geographic distribution of the hurricane property damages; the two states' insurance market responses to record hurricane losses; the effect of those changes on different interest groups' policy demands, as well as policymakers' assessment towards the stability of the existing homeowner insurance (and wider economic) order; and the success of the former in influencing the latter.

I obtained hurricane property damage data from the Spatial Hazard and Losses Database for the United States ("SHELDUS"). Data for the changing property insurance market structures came from the existing insurance economics literature and a variety of public and private data sources including the U.S. Census Bureau, the Insurance Information Institute ("iii"), the Property Insurance Plans Service Office ("PIPSO"), AM Best's special and statistical reports, the National Association of Insurance Commissioners ("NAIC"), and the two state regulators' annual reports. To trace the prevailing institutional environments in which the policy process played out, including the legitimacy of the dominant and competing insurance market logics and associated state interventions, I drew on opinion polls and on newspaper reports about the homeowner insurance market and related policy proposals and debates obtained via keyword searches from Factiva. Regional newspapers reported extensively on the impact and broader societal and political repercussions of the 2004 and 2005 hurricane shocks and offered rich insights into popular expectations and attitudes toward the economic and political fall-out from the hurricanes.

Insurer, real estate, and other interest groups' political goals and demands were inferred from their publicized policy proposals, from public comments by their officials, and from their policy papers designed to influence the legislature. The political resonance of the latter as well as the different groups' official financial electoral contributions served as an additional measure of their political influence. Official financial electoral contributions are compiled on the comprehensive followthemoney.org database. State legislative election results were obtained from the Inter-University Consortium for Political and Social Research database no. 43297. Regulators' policy positions were inferred from their written policy recommendations, official public comments, and their actual regulatory responses to hurricane shocks. State officials' positions and strategies were reconstructed from public comments and speeches by key officials involved in insurance policymaking, their legislative activity surrounding homeowner insurance, and from their voting records. Data regarding all other aspects of the political and legislative 
processes were directly obtained from the respective state legislatures' online archives in the form of the procedural history of each law, its voting record, and legal digests and commentaries.

I triangulated my interpretation of all of above sources with fourteen in-depth interviews with leading insurance regulators, legislators, and interest group executives involved in critical aspects of the policy processes in both states, industry experts' written commentaries such as the "Property Insurance Report," and the insurance economics literature describing the market and regulatory responses to the 2004 and 2005 hurricane seasons.

\section{Process tracing of policy responses relating to homeowner insurance, 2004-2008}

The 2004 and 2005 hurricane landfalls only indirectly affected the observed homeowner insurance legislation in 2007. Taking as guidance the theoretical expectations of SCT and IGT and the key differences in background conditions identified in Table 1, this section traces the processes that link the 2004 and 2005 hurricane damages to those intervening events that together generated the different policy outcomes in Florida and Louisiana: the hurricane shocks and homeowner insurance market failures (section 4.1), the associated insurance legitimacy crises (4.2), the various interest groups' political demands to solve the perceived crises and the pre-election policy responses (4.3), the eventual electoral impact of the crises (4.4), and the legislators' policy decisions in response to the electoral pressures and their own preferences (4.5).

\subsection{Hurricane shocks and insurance market disruptions, 2004-2006}

The 2004 and 2005 hurricanes caused private homeowner insurance market failures that triggered the political process that culminated in the contrasting insurance policy changes in the two states in 2007. There exists widespread evidence that, other things being equal, ${ }^{4}$ voluntary property insurers tend to overweigh recent events and refuse to extend or offer new coverage in response to unexpectedly large hurricane losses (Aseervatham et al., 2015; Born and Klimaszewski-Blettner, 2013; Burt et al. 2009; Kunreuther et al., 2013, p. 175). Property insurers also tend to charge actuarially excessive premiums when the risks of future losses are ambiguous (Kunreuther et al., 1995, 2013), as they are in the case of hurricanes. In response to the unexpectedly severe 2004 and 2005 hurricane shocks, private insurers in both states decreased their high-risk coastal coverage as old policies ran out and actively sought to increase 
insurance premiums on outstanding insurance contracts. ${ }^{5}$ These market changes created voluntary homeowner insurance affordability and availability crises in both states.

Following the record damages caused by Hurricane Andrew in 1992, property insurers along the Gulf of Mexico had adopted forecasting models designed to help refine their forecasts of future hurricane losses (Grossi and Kunreuther, 2005). In line with these models, they gradually increased insurance rates and adjusted their risk exposure. By the early 2000s, property insurance markets had stabilized and insurers as well as regulators saw them as sufficiently prepared to absorb future hurricane shocks (Cummins et al., 2002; Grace and Klein, 2006, p. 2). Climate models can predict increases in hurricane frequency and intensity, but cannot predict exactly where and when hurricanes will hit and what degree of destruction they will cause (Melillo et al., 2014, p. 27). ${ }^{6}$ The intensity and location of the 2004 and 2005 hurricane shocks caught all market participants by surprise. In response to the heightened uncertainty (Knight, 2006) regarding their long-term profitability and even survival, private homeowner insurers in both states scaled back their exposure and sought to increase prices on the policies they continued to write in both states.

Owing to the original role of residual programs as insurer-of-last-resort, the size and growth of the residual market is the best available measure of voluntary homeowner insurance availability in Florida and Louisiana (Grace et al., 2005, p. 21; Klein, 2009, p. 71). ${ }^{7}$ Florida's residual market share climbed from 10\% in 2003 to $16 \%$ in 2006 and in Louisiana from 5\% to $8 \%$. A year later, in 2007 , the share rose to $18 \%$ in Florida and to $10 \%$ in Louisiana. ${ }^{8}$ This growth in both states was predominantly driven by voluntary insurance supply retrenchment in high-risk coastal counties. The difference in growth rates mainly reflects Florida's relatively larger coastal insurance exposure, and suggests a greater state-wide voluntary homeowner insurance availability problem in Florida than in Louisiana in the immediate aftermath of the 2004 and 2005 hurricane seasons (Klein, 2009, pp. 73-75).

When it came to voluntary insurance affordability, regulators in both states did not meaningfully resist significant homeowner insurance premium hikes, in Florida at least not until late 2006. Between 2003 and 2007, average statewide homeowner insurance premiums increased by $89 \%$ in Florida and $44 \%$ in Louisiana (Insurance Information Institute, 2012). Florida's greater coastal exposure again largely explains the growth differentials. In both states, many 
high-risk coastal counties suffered dramatically larger increases, sometimes by up to $300 \%$ (Grace and Klein, 2006, pp. 31-40; Klein, 2009, pp. 59-67).

Together, Florida and Louisiana's private insurance supply and especially price shocks disrupted the pre-2004 and 2005 insurance equilibrium and caused significant economic hardship to homeowners seeking to renew their insurance in both states in 2005 and 2006, creating widespread concerns regarding the potential wider negative economic repercussions. The insurance disruptions in turn triggered insurance legitimacy crises and increasingly organized public calls for a reform of the insurance system in Florida, though not in Louisiana.

\subsection{Legitimacy crisis and protest, 2005-2006}

The second step in the process connecting the material hurricane damages to the policy outcomes of interest consists of the impact of voluntary insurance market disruptions on the legitimacy of the overall homeowner insurance system and associated protests. In Florida, the exposure of the majority of the population to insurance price hikes challenged the legitimacy of the existing insurance order. In contrast, the worst of Louisiana's homeowner insurance market disruption affected a smaller and more marginalized segment of the population. The public's attention instead focused on the perceived failure of the federal and local state to prevent the flooding of New Orleans and the city's subsequent rebuilding. Consequently, the state's crisis management and not the existing voluntary insurance order suffered legitimacy problems in Louisiana. Schneiberg and Bartley's (2001) study of fire insurance regulation adoption indicates that private insurer-induced legitimacy crises can help consumer groups to organize. In line with this finding, the legitimacy crisis in Florida aided the political mobilization of homeowners and their allies. No such comparatively effective mobilization took place in Louisiana.

\section{Florida}

In Florida, the eight hurricane landfalls in 2004 and 2005 had the most damaging effect on counties with a majority of the state's (White) population. Most Floridians were consequently either directly or indirectly exposed to the subsequent homeowner insurance cost increases and supply reductions. The state's media systematically discussed insurance matters and market developments, further raising the public salience of hurricane-related homeowner insurance affordability and availability challenges along the coast. In 2006, media reports of the return to 
profitability of the voluntary homeowner insurance sector in the absence of new hurricane shocks (Klein, 2009, p. 81) solidified the evolving public perception that the insurance sector was acting unfairly and opportunistically.

The associated erosion of the legitimacy of the existing insurance order provided the impetus for more organized political action. Starting in early 2006, homeowner groups and residential developers mobilized not only against price increases but against the overall homeowner insurance order. The grassroots insurance advocacy group "Homeowners against Citizens," for example, formed in March 2006 to lobby for affordable residual insurance premiums. Later that year, however, the group changed its mission and name to "Having Affordable Coverage Florida," because "it became evident that most of the problems that Citizens Insurance had was not because of Citizens but because of legislation that Citizens had to follow" (Florida Homeowners Insurance Information, 2006a). Like these groups, others evolved from protesting insurance price increases to demanding more systematic insurance market reform. A series of Florida Chamber of Commerce surveys during 2006 consistently ranked homeowner insurance prices as the top public concern. Regarding concrete solutions to this concern, $63 \%$ of voters backed an expansion of subsidized property insurance coverage of the residual insurer Florida Citizens according to a Quinnipiac University poll in late 2006. In other words, during the course of the state's election year, a majority of Florida's public became concerned about rising insurance prices, and started to support an expansion of (subsidized) state-backed insurance as solution. The "fairness" of the existing insurance system consequently became a central issue in the state elections.

\section{Louisiana}

In contrast to Florida, in Louisiana, the public response to insurance market disruptions was significantly less pronounced. Homeowner insurance affordability and the organization of its provision were conspicuously absent from the public discussion in the aftermath of hurricanes Katrina and Rita. Instead, the public's attention focused on the responsibility of all three levels of government for the extensive flood damage from the two hurricanes, the state's perceived inadequate, delayed, and racially biased rebuilding efforts, and private insurers' seemingly opportunistic claim payouts (Hartman and Squires, 2006; Brunsma et al., 2010). 
Hurricane Katrina, the costliest natural disaster in U.S. history, made landfall close to New Orleans. The accompanying storm surges caused extensive flooding that submerged $80 \%$ of the city and large parts of the neighboring parishes (McCarthy et al., 2006). A month later, Hurricane Rita further aggravated this flooding. As a result, $72 \%$ of the 188,251 housing units in New Orleans were damaged, with $56 \%$ having major or severe damage, mostly from flooding (U.S. Department of Homeland Security, 2006). The flooding damage triggered the evacuation of about $70 \%$ of the residents in New Orleans (Frey et al., 2007). The hardest hit neighborhoods with the greatest overall population losses and slowest return rates were those with predominantly minority populations. The constituency that was worst affected by private homeowner insurance coverage shortages and price increases was therefore also small relative to the state's overall population.

The broader public's attention consequently centered on issues other than homeowner insurance affordability and availability. Most prominently, public discussion focused on the perceived state and government failure to prevent the flooding damage in the first place and to help the hardest-hit neighborhoods to rebuild. Secondly, because voluntary or residual homeowner insurance only covers wind damage, private insurers systematically delayed homeowner claim payouts. Insurance companies initially refused to meet the 1.2 million Katrinarelated property insurance claims resulting from wind-driven hurricane flood damage (Hartwig and Wilkinson, 2010). To a lesser degree, public attention therefore also focused on voluntary insurers' claim-making processes. The ensuing lawsuits and the resistance of private insurers to pay their customers created considerable public and legislative misgivings about voluntary insurance behavior, although not about the overall insurance order as such. According to a Louisiana State University survey, only a few months before the state elections in May 2007, primary public attention had shifted away from issues surrounding the rebuilding of New Orleans but had not yet coalesced on another issue, certainly not on the fairness or general order of the existing homeowner insurance market system.

In summary, the state-specific geographic and temporal distributions of hurricane landfalls, the type of hurricane damage, and the racial and socio-economic characteristics of the worst affected populations were critical factors in creating different legitimacy crises in the two states. In Florida, the temporally and geographically more widely distributed costs from private insurance price increases, as well as the sector's widely reported return to profitability, 
challenged the legitimacy of the existing homeowner insurance market system. In Louisiana, public scrutiny rested on the state's capacity and willingness to prevent and help residents recuperate from flooding-related hurricane damage in New Orleans, as well as private insurers' perceived opportunism regarding claim payments. Public attention did not focus on the fairness of the existing insurance order as such.

\subsection{Pre-election demands and policy responses, 2005-2006}

What concrete political demands did different interest groups make in response to the voluntary insurance market disruptions and related legitimacy crises in the two states? How did legislators react to these demands, and what policies did they implement before the state elections in Florida in late 2006 and in Louisiana a year later? Political demands arising from the insurance market disruptions and the associated legitimacy crises, and the immediate policy responses to them, constitute the next steps in the process that links the 2004 and 2005 hurricane shocks to the policy outcomes in 2007. In Florida, a critical and organized mass of homeowners demanded concrete insurance market reforms that would weaken the reliance on private market homeowner insurance provision. Despite these public demands and broader public pressure, Republican legislators continued to follow the prevailing free-market and pro-voluntary insurance provision orthodoxy. In Louisiana, where there was an absence of comparable public challenges and legitimacy crises to the existing insurance system, legislators continued to follow the provoluntary market policy logic that the state had adopted before the 2005 hurricane shocks.

\section{Florida}

Starting in 2005, coastal homeowner protest groups were "popping up everywhere" to highlight the affordability crisis in Florida's homeowner insurance system and its negative effects on the wider economy (Zucco, 2006). The aforementioned group, Having Affordable Coverage Florida, counted 1,000 members by late 2006. Another group, Fair Insurance Rates in Monroe, grew from its original 32 members in 2006 to 3,000 members today. Both joined a wider coalition of homeowner groups comprising, by their own accounts, over one million members (Florida

Homeowners Insurance Information, 2006b). ${ }^{9}$ Leading up to the state elections in late 2006, these groups used town hall meetings, letter-writing campaigns, and protest rallies to 
systematically lobby legislators and regulators and propose concrete solutions to what they framed as an unfair insurance system.

With respect to escalating insurance prices, the key demand was the replacement of the existing use-and-file rating system that allowed voluntary insurers relatively large pricing flexibility with a more restrictive prior-rate approval system that would give regulators greater discretion over insurance rate changes. ${ }^{10}$ Protest groups also proposed the transformation of Florida Citizens into a fully competitive insurance provider that could offer subsidized or, in their mind, fairly priced insurance to everyone who applied — not just to homeowners who could not obtain coverage in the private market.

Voluntary homeowner insurance associations and lobbying firms framed insurance affordability problems as an issue of regulatory-induced market inefficiency that aggravated the ongoing voluntary insurance supply retrenchment. They argued, in line with the prevailing freemarket economic logic, that homeowners' demands for greater state intervention would impede rather than promote competition, reduce voluntary insurance supply, and therefore further increase prices and harm homeowners in the long run. Using widely disseminated studies, direct lobbying, and testimonials before legislative committees, insurers consequently proposed a transition to a market-based rate-making system to create greater pricing flexibility. According to them, this kind of deregulation of the homeowner insurance market combined with additional monetary incentives to attract new private insurers to the state would eventually increase voluntary insurance supply and lower insurance rates (AM Best, 2005; Harrington, 2005). In legislative sessions leading up late 2006, the Republican majority in both state houses sidelined homeowner demands for greater state repression of private insurance market forces and instead opted to adhere to the prevailing free-market logic, although not to extent demanded by insurance groups.

The legislative session in early 2005 created a 12 -member task force to determine whether, following the record 2004 hurricane season, Florida had sufficient private insurance capacity to ensure the continuation of a healthy, competitive marketplace, and to identify the future demands on Florida's hurricane insurance markets. In the wake of the second set of record hurricane landfalls in 2005 and a day before the opening of the 2006 legislative session, the task force recommended that "maintaining and expanding competitive conditions in the Florida private sector property insurance market is critical to the economic viability of the state" (Florida Office 
of Insurance Regulation, 2006, p. 6). In particular, it argued that rate increases and greater pricing certainty were critical in attracting new and expanding existing voluntary insurance in Florida, and therefore safeguarding healthy levels of market provision of homeowner insurance.

In the subsequent 2006 legislative session, Republican lawmakers in both houses worked to implement these recommendations. Their majorities allowed them to essentially ignore the Democrats' support for homeowner demands (Ostrowski, 2006). Eventually, the House and Senate compromised on an insurance bill (SB1980) that, among other provisions, made it more difficult for the state regulator to reject voluntary rate increases. ${ }^{11}$ It also created the Insurance Capital Build-Up Incentive Program that incentivized coverage expansion by existing or new voluntary homeowner insurers. The law additionally required the residual insurer to base its future rates on hypothetical reinsurance costs, thereby locking in residual rate increases to $20 \%$ from 2007 onwards. William Stander, regional manager for the insurance lobby group Property Casualty Insurers Association of America, called the bill "a good start," even though some of the insurer demands such as a move to a full market-based rate making system had been watered down (AM Best, 2006). In short, leading up to the state elections in late 2006, the Florida state legislature pursued the kind of free-market solutions that were favored and formulated by the insurance industry and taken for granted in Florida's wider political economy.

\section{Louisiana}

In Louisiana, the legislature continued to pursue a pro-voluntary insurance policy advocated for by the state's insurance regulator and supported by leading legislators and the governor even before the 2005 hurricane season. A coalition of business groups which included homeowner insurers, though only as junior partners, actively supported this policy direction and provided concrete policy suggestions starting in 2006. Due to the large emigration of New Orleans's hardest hit hurricane victims, homeowner mobilization against rate increases and for an expansion of subsidized residual insurance provision never became as widespread, organized, or effective as in Florida.

Mainly due to its small market size and widely perceived restrictive and even corrupt regulatory and legislative environment, Louisiana historically had difficulties in attracting sufficient voluntary homeowner insurance supply and reduce market concentration. ${ }^{12}$ In this context, starting in 2000, incoming Insurance Commissioner Wooley started to lobby the 
legislature and the governor to clean up the state's insurance governance regime, attract more voluntary insurers to the state, and minimize regulatory and state intervention in and exposure to the insurance market. He also engaged in a systematic outreach campaign to rebuild the trust of private insurers in the state. He did so because "government does not do a good job running things" and "if we do what's right, everything else will take care of itself." "What's right" here refers to the deepening and widening of private insurance market provision and the reduction of the state's role in it. By eliminating government and regulatory rent seeking and by establishing more transparent and uniformly enforced rules, the state could establish an environment which would increase private insurance market competition and efficiency. This would eventually maximize aggregate societal benefits. Leading legislators and Governor Blanco were sympathetic to this approach and, as a first concrete step, created Louisiana Citizens as strict and uncompetitive insurer-of-last-resort in 2004.

The absence of any voluntary insurance insolvencies and a relatively low exodus of voluntary insurance from the market led to Louisiana's voluntary homeowner insurance supply remaining relatively more stable than Florida's post-2005. The largest private insurers did not take any concrete steps to exit the state. ${ }^{13}$ According to the regulator, industry representatives, and legislators directly involved in the decision-making at the time, the governor and the most influential legislators all interpreted this relative stability as a success of Commissioner Wooley's previous trust-building efforts. This warranted the continuation of the pro-voluntary market approach initiated before 2005. In contrast to post-2006 Florida, scattered homeowner demands received no significant legislative attention or support.

The 2005 special legislative session following hurricanes Katrina and Rita did not directly engage with the issues of voluntary homeowner insurance affordability or availability. Most crucially for our purposes, legislators adopted a state-wide building code (SB44) that Commissioner Wooley had long argued would increase voluntary insurer willingness and ability to expand homeowner insurance in the state. Moreover, none of the legislative sessions during the following year adopted policies that concretely expanded or restricted the residual or voluntary homeowner insurance markets either.

Starting in 2006, however, business concerns grew about the potentially negative effect of affordability and availability problems in the voluntary homeowner insurance markets for the ongoing rebuilding effort and wider economic performance. In close coordination and 
cooperation with Louisiana's insurance regulator, and in line with the pro-voluntary approach favored by the governor and leading legislators, a large and diverse group of businesses - the Coalition to Insure Louisiana - acted on these concerns and developed a detailed 15-point plan to render the voluntary homeowner insurance market more attractive to outside insurers, reduce insurance rates, and ultimately aide the rebuilding efforts. Bankers, realtors, and homebuilders spearheaded the Coalition. The insurance industry participated but did not lead its efforts to formulate concrete pro-voluntary insurance policy proposals. In the eyes of the leading legislators and Governor Blanco, the broad scope of the Coalition rendered it essentially representative of the wider economy. Its testimonies in support and refinement of the state's existing free-market course not only helped to dismiss the few lingering demands for the expansion of subsidized residual insurance by some homeowners and their Southern lawmakers; it also signaled to lawmakers that more concrete pro-voluntary legislative interventions were required to shore up the wider economy.

In the subsequent 2007 legislative session, lawmakers adopted most of the regulator and Coalition's proposals. Policymakers created the Insurance Louisiana Incentive Program (HB678) that, similar to the 2006 incentive program in Florida, matched committed voluntary insurance coverage with state grants, while requiring grant recipients to absorb some of the existing residual insurance coverage. The state also sought to limit the role of the residual homeowner insurer by requiring Louisiana Citizens to charge even less competitive rates (HB962), and streamlined the process by which voluntary insurers could take over residual policies (SB153). All three laws were deliberately designed to attract more voluntary insurers and facilitate the shift of hurricane risks from the state to the private insurance market. Regarding homeowner insurance prices, legislators opted to increase private insurers' pricing flexibility by abolishing the Insurance Rating Commission that had previously reviewed every rate increase above $10 \%$ (HB960).

In summary, for all practical purposes, Florida and Louisiana adopted very similar homeowner insurance policies designed to strengthen and deepen the voluntary market provision of insurance. Leading up to their state elections in late 2006 and 2007 respectively, legislators responded to hurricane-induced homeowner insurance market disruptions by following the freemarket logic that was institutionalized in the wider political economy in both states. Florida did so amidst significant public criticism of the existing insurance system. Louisiana faced no 
comparable public opposition. To the extent that the largest insurance groups influenced these policy decisions, they did so by collaborating with pro-market legislators and by offering concrete policy suggestions rather than threatening to exit the market.

\subsection{State elections, 2006 and 2007}

While both states sought to strengthen and deepen voluntary homeowner insurance provision in direct response to the 2004 and 2005 hurricane damages, the subsequent state elections changed the policy direction in Florida but not in Louisiana. In Florida, the 2006 state elections offered homeowner and real estate groups the structural opening to more effectively and successfully pressure legislators to alter the existing insurance provision system. In Louisiana, issues of homeowner insurance affordability or availability never became a salient electoral topic. The state's existing strategy of expanding voluntary homeowner insurance in order to strengthen the overall economy was never effectively challenged and persisted after the elections.

\section{Florida state elections, 2006}

Between 2005 and 2007, the free-market policies pursued in Florida failed to prevent a 42\% increase in state-wide average homeowner insurance premiums, as well as continued voluntary insurance retrenchment. By the end of 2006, homeowners' political lobbying combined with sizable electoral contributions from residential developers and real estate groups rendered homeowner insurance affordability issues sufficiently salient to turn them into the central pillar of the gubernatorial election and, more generally, into one of the central themes of the 2006 state election.

Republican gubernatorial candidate State Attorney General Charlie Crist set the tone of the election by tapping into the public anger surrounding homeowner insurance pricing and built much of his campaign on attacks on the insurance sector, portraying private insurers as profithungry and exploitative. With financial backing of \$2.5 million from the real estate sector and only $\$ 433,200$ from the insurance industry (out of a total of $\$ 24.2$ million), Crist won the race with a comfortable 7\% margin. Real estate agent and developer electoral contributions also trumped those of property insurers and insurance agents in Senate and House races (see Table 1 above) and helped to at least marginally shift power in the legislature. While Republicans retained control of the House and Senate, Democrats, who had been more willing to align 
themselves with homeowner and real estate demands for a reform of the insurance system to achieve lower rates, rid the GOP of its two-thirds House majority. This election outcome meant that the Republicans could no longer ignore Democratic proposals and generally gave homeowners and developers a greater voice in the legislative process. Additionally, by criticizing the pro-market insurance bill (SB1980) that came out of the Republican Senate in 2006, the Democrat Alex Sink beat Republican Senate president Tom Lee to the office of Chief Financial Officer of the state, becoming the first Democrat to win a statewide race since $1998 .{ }^{14}$

\section{Louisiana state elections, 2007}

In Louisiana by mid-2006, the slow return-migration of residents and widespread dissatisfaction with the state government's rebuilding efforts made it increasingly doubtful whether the Democratic Party would be able to amass the 100,000-vote margin it traditionally needed for statewide victory. ${ }^{15}$ The 2007 election also marked the first time policymakers would be vacating their House seats as a result of a 1995 law that enacted a 12-year legislative term limit. As a result, Republicans and their business allies saw the 2007 elections as a unique opportunity to take over the House and governorship (Barnes, 2006). Crucially, however, neither party regarded voluntary insurance affordability as a sufficiently salient issue to prioritize in the elections. Instead, issues of government ethics, construction, health care, education, transportation, and workforce training dominated electoral debates. Ultimately, the GOP failed to gain the majority of the House or Senate as hoped. Still, Republican Bobby Jindal succeeded in wrestling the governorship from Democrats, while incumbent Insurance Commissioner Donelon's landslide reelection likely resulted in a large part from his perceived leadership in the creation of the voluntary market oriented insurance incentive program earlier that year.

In summary, homeowner and real estate groups in Florida successfully propelled the homeowner insurance affordability crisis to the center of the electoral debate, where their framing of the existing insurance order as unfair was embraced by important winning campaigns. In Louisiana, a similar mobilization did not occur and the institutionalized policy focus on private insurance market efficiency was never electorally challenged.

\subsection{Post-election policy directions}


The final step in the process that links the 2004 and 2005 hurricane landfalls to the 2007 insurance policy outcomes consists of the policy decisions made by legislators following the state elections in 2006 and in 2007. In Florida, electoral pressures influenced lawmakers' decisions to expand subsidized residual insurance provision and restrict voluntary insurers' flexibility. In contrast, Louisiana saw legislators continuing to follow the prevalent and institutionalized free-market and pro-voluntary insurance policies.

A month after the Florida elections, House members met for three days to discuss the upcoming special session on homeowner insurance reform called by Governor-elect Crist. In a significant turnaround from pre-election attitudes, leading Republican lawmakers concluded that a much larger role for the state in homeowner insurance provision had become inevitable (Diamond, 2006; Stockfisch, 2007). Republican Senator Atwater, for example, noted that "the financial risk associated with Florida's fiercest forces of nature can no longer be borne by the homeowner alone" (Stockfisch, 2007). The incoming Republican head of the Senate's Banking and Insurance Committee publicly stated that he did not look forward to government getting more involved in insurance but just saw no alternative. Lawmakers publicly justified this turnaround by stressing that they had previously been misled by the insurance sector. ${ }^{16}$ They claimed that contrary to the claims of voluntary insurers based on their catastrophe models, the existing voluntary insurance rate increases were not necessary for voluntary insurers' survival and the associated health of the insurance market. The return to positive profits in the absence of new hurricane landfalls in 2006 and 2007 proved that voluntary rate increases occurred at the expense of coastal homeowners; homeowners had thus been correct in claiming that private insurers were acting opportunistically.

During the ensuing special legislative session, the House and Senate debated the form of the curtailing of voluntary insurance markets and the bailing out of homeowners. While a part of the Republican-dominated House continued to favor free-market options, by the end of the session lawmakers approved bill CS/HB1A, which involved the expansion of de-facto subsidized residual homeowner insurance. The bill rolled back the earlier Florida Citizens rate increase and froze its rates at arguably artificially low levels until January 2009; it also offered access to residual insurance to anybody who received a voluntary insurance quote that was more than 15 percent above the residual rates and forced voluntary insurers to write homeowner insurance if they participated in the lucrative auto insurance sector. Some House Republicans commented 
that the bill was socialist. However, in a speech marking the passage of the bill, Republican Governor Crist again attacked the insurance industry for exploiting "every crack and crevice they can contemplate to rip more money from the pockets of our people" and thanked lawmakers for putting "the nail in the coffin of the industry that was hurting our people" (Follick and Dunkelberger, 2007).

In Louisiana, the absence of any significant electoral pressure regarding homeowner insurance meant that legislators continued to draw on free-market policy prescriptions to strengthen insurance affordability and availability. The 2007 elections introduced no substantial changes in policymakers' attitudes toward the homeowner insurance market. The main homeowner insurance bill (SB160) in the legislative session following the election enabled greater voluntary insurer rate discrimination in 2008.

\section{Discussion and conclusion}

Following the record 2004 and 2005 hurricane seasons, why did Florida turn to the state to become a central provider of homeowner insurance in high hurricane-risk regions, while Louisiana continued to rely on the private insurance market? In Florida, temporally stretched out hurricane damages and the subsequent growth of homeowner insurance prices affected a larger, geographically more dispersed, and predominantly White segment of the overall population than in Louisiana. The widely distributed hurricane impacts triggered political mobilization by coastal homeowner groups and their allies, ultimately resulting in the popular reframing of insurance market disruptions as an issue of fairness rather than a lack of market efficiency. As demonstrated by the pre-election, pro-voluntary insurance policy adoptions in Florida, the mobilization was, however, only necessary but not sufficient for lawmakers to abandon institutionalized free-market policies. Political opportunity was additionally required to allow homeowners and their allies to translate their political demands into tangible legislative outcomes. The 2006 state elections provided such an opportunity.

In Louisiana, even before the 2005 hurricane shocks, the insurance regulator, with support from the governor and key legislators, were actively pursuing a campaign to deepen and strengthen the private insurance market and to minimize what they perceived as harmful state interferences with it. After the 2005 hurricane disruptions, leading lawmakers faced a relatively unorganized public backlash against growing insurance prices that never systematically 
challenged the existing policy stance. A broad coalition of businesses that highlighted potential threats of homeowner insurance affordability and availability problems to the reconstruction effort signaled to state officials that more direct pro-market interventions were required to support the wider economy in 2007.

The policy dynamics and processes emphasized by IGT and SCT played a key role in generating policy responses in both states. The comparison of the two states indicates, however, that different dynamics and processes emerged in the two settings, supporting a more general claim regarding states' insurance policy responses to hurricane and potentially other extreme weather event disruptions. The type of homeowner insurance policy response to larger-thanexpected (hurricane) shocks and the associated homeowner insurance market disruptions depends on the temporal, geographic, demographic, and socio-economic distribution of the shocks at the conjunction of political, and especially electoral, opportunity. A broader distribution of the largest disaster costs across relatively more resourceful homeowners should trigger political mobilization that is able to use timely elections to initiate policies that challenge the institutionalized free-market policy logic. A narrower distribution of the largest disaster costs should fail to generate politically significant group opposition and allow the capitalist state to reproduce institutionalized free-market policies, even if timely electoral openings should arise.

The differences in homeowner insurance market structures in the two states and the structural power they offered the insurance sector seem to have had less of an impact on the policy processes and their outcomes than the distribution of hurricane losses combined with timely state elections or state officials' adherence to institutionalized free-market policy prescriptions. In Louisiana, the relatively smaller size of the insurance market in principle allowed the largest insurers to make credible threats to leave the state altogether, and thereby to influence rule-making. Although the legislative outcomes in the state were supportive of the private insurance sector, the evidence does not indicate that exit-threats or other direct pressures from private insurance groups significantly affected the observed legislative outcomes. In Florida, the substantially larger homeowner insurance market and the lucrative auto insurance market, together with the smaller insurance market concentration, made potential exit threats less credible. The additional widespread public opposition to the existing free-market insurance logic suggests that lawmakers could have relatively easily adopted less market-friendly policies in support of homeowners in the run up to the election in 2006. Florida's legislators did not do so, 
but instead sought to strengthen private insurers. The tracing of the policy processes in the two states suggests that SCT processes, mainly in the form of legislators' adherence to comparable free-market policy solutions to insurance affordability crises, figured centrally in both states before 2007. IGT processes in the form of effective homeowner group electoral pressure explain the break with pro-market policies in Florida in early 2007.

Pavalko (1989) used SCT to explain the timing of the adoption of worker insurance compensation programs; the factors and processes highlighted by this theory also seem to explain Louisiana policymakers' continued adherence to free-market insurance policies. They did so not primarily because of interest group pressure, but mainly because these policies constituted what leading lawmakers believed to be the most effective means to address perceived homeowner insurance market frictions and failures that threatened the wider economy. While business groups supported this course post-hurricanes Katrina and Rita, they did not initiate it.

IGT was employed in Fishback and Kantor's (1996) explanation of the adoption of stateonly worker insurance programs in the U.S. This theory also captures the situation in Florida, where interest groups composed of homeowners and their allies challenged taken-for-granted free-market economic policy prescriptions. This challenge was, however, not sufficient to convince legislators to abandon the institutionalized free-market legislative agenda they pursued throughout 2006. Only the occurrence of state elections allowed homeowners to exert sufficient electoral pressure to change legislative behavior.

The analysis and findings suggest one avenue for theoretical synthesis. IGT and SCT both help explain states' responses to hurricane shocks. But as the analysis indicates, which dynamics and processes emerge and which theory applies depend on factors outside those theories - the shocks' temporal, geographic, demographic, and socioeconomic distributions in conjunction with the timely opening of political opportunities. SCT applies when shocks are relatively concentrated. IGT applies when the cost shocks affect a broader part of the population and the opening of political opportunities allow the affected groups to pressure legislators to address their grievances outside the institutionalized policy prescriptions.

The findings also draw attention to the distribution of unexpected cost shocks at the conjunction of political opportunity as a critical factor that can help delineate the contingency of the form and location of policy-making power in other crisis contexts. Greater consideration of this factor might, for example, contribute to longstanding debates between instrumentalist and 
structuralist theories of the state as well as more recent but related discussions about the role of structural as opposed to interest group power in shaping regulatory responses to the 2008 financial crisis (e.g. Culpepper et al., 2014; Woll, 2016). As in the cases of Florida and Louisiana, the different policy dynamics proposed might critically depend on the distribution of the problems and shocks involved.

In order to adequately test this contingent general claim, future studies should investigate the open question of what exactly constitutes a broad as opposed to a narrow distribution of unexpected shocks and the size of those shocks necessary to trigger effective political group mobilization and policy change. Such studies could, for example, conduct comparative analyses of the effects of varying distributions of unexpected (extreme weather) cost shocks on the likelihood of successful political and electoral mobilizations against institutionalized policy responses; these can be examined in the context of both political openings and blockages. Additional research could investigate the limits of possible structural transformation of homeowner insurance systems in response to weather-related political mobilization in capitalist economies. Sufficiently large future weather-related shocks might not only overwhelm the capacity of voluntary insurance markets to cover the resulting costs (Cummins et al., 2002), but also conceivably surpass individual states' ability to reproduce the dominant economic order. An expansion of subsidized residual insurance provision to ease insurance affordability crises and their negative effects on the wider economy might not be possible in response to extraordinarily large weather shocks. Amidst the growing frequency and intensity of extreme weather events, a better understanding of the capacity of existing capitalist insurance systems to absorb such shocks and of the processes that lead to the adoption of policy innovations will be critical for building not only a more resilient but also a fairer future. 


\section{References}

AM Best (2005, January 20) 'New Fla. Legislative Committee Hears Views on Hurricane Insurance Issues', Bestwire.

AM Best (2006, May 16) 'Florida Governor Signs Property Insurance Reform Bill', Bestwire.

Aseervatham, V., Born, P., Lohmaier, D. and Richter, A. (2015) Putting Everything Under the Same Umbrella - Hazard-Specific Supply Reactions in the Aftermath of Natural Disasters, MRIC Working Paper No. 25, Munich, Munich Risk and Insurance Center.

Barnes, F. (2006, May 8) 'Post-Katrina Politics', The Weekly Standard, Baton Rouge, LA.

Barrese, J. and Nelson, J. M. (1994) ‘Some Consequences of Insurer Insolvencies', Journal of Insurance Regulation, 13, 3-18.

Bennett, A. and Checkel, J. T. (2015) 'Process Tracing: philosophical roots to best practices', in Bennett, A and Checkel, J. T. (eds) in Process Tracing: From Metaphor to Analytic Tool Cambridge, Cambridge University Press, pp. 3-38.

Bohrer, B. (2007, November 14) 'Balance of power may be shifting in Katrina-shaped New Orleans', The Associated Press Newswires, APRS.

Born, P. H. and Klimaszewski-Blettner, B. (2013) 'Should I Stay or Should I Go? The Impact of Natural Disasters and Regulation on U.S. Property Insurers' Supply Decisions', The Journal of Risk and Insurance, 80, 1-36.

Brunsma, D. L., Overfelt, D., and Picou, J. S. (2007) The sociology of Katrina: Perspectives on a modern catastrophe, Lanham, MD: Rowman and Littlefield.

Bureau of Economic Analysis (2016) Regional Data - GDP \& Personal Income, accessed at http://www.bea.gov/iTable/index_regional.cfm on June 30, 2016.

Burt, L., Carlson, C., Kuerca, J. and Massie, J. (2009) 'Florida Homeowners Insurance: How Big Is the Availability Problem And Is There A Fair Solution?', Risk Management and Insurance Review, 2, 183-197. 
Culpepper, P. D. and Reinke, R. (2014) 'Structural Power and Bank Bailouts in the United Kingdom and the United States', Politics and Society, 24, 1-28.

Cummins, J. D., Doherty, N., and Lo, A. (2002) 'Can Insurers Pay for the "Big One”?

Measuring the Capacity of the Insurance Market to Respond to Catastrophic Loss', Journal of Banking and Finance, 26, 557-583.

Dahl, R. (1961) Who Governs?, New Haven, Yale University Press.

Diamond, R. (2006, December 6) 'Planned Citizens increase may die', The Palm Beach Post, Palm Beach, FL, PMBP.

Elsner, J.B., Kossin, J.P., and Jagger, T.H. (2008) 'The increasing intensity of the strongest tropical cyclones', Nature, $\mathbf{4 5 5}, 92-95$.

Falleti, T. G. and Mahoney, J. (2015) 'The comparative sequential method'. In Mahoney J. and Thelen K. (eds) Advances in Comparative-Historical Analysis, Cambridge, Cambridge University Press, pp. 211-239.

Fishback, P. V. and Kantor, S. E. (1996) 'The Durable Experiment: State Insurance of Workers' Compensation Risk in the Early Twentieth Century', Journal of Economic History, 56, 809-36.

Fishback, P. V. and Kantor, S. E. (1997) The adoption of workers' compensation in the United States, 1900-1930, Working Paper 5840, Cambridge, National Bureau of Economic Research.

Follick, J. and Dunkelberger, L. (2007, May 5) 'Crist notches wins, but tax reform stalls; Insurance package pleases governor, but taxpayer relief will wait till June', Sarasote HeraldTribune, Sarasota, FL, SSTA.

Florida Homeowners Insurance Information (2006a) Having Affordable Coverage Florida, accessed at http://www.floridahomeownersinsuranceinfo.com/Homeowners-Insurance-FloridaHAC/Having-Affordable-Coverage-Florida.html on September 15, 2014. 
Florida Homeowners Insurance Information (2006b) HAC Florida Insurance, accessed at http://www.floridahomeownerinsurances.com/Homeowners-Insurance-Florida-HAC/HACFlorida-Insurance.html on August 3, 2016.

Florida Office of Insurance Regulation (2006) Task Force on Long-Term Solutions For Florida's Hurricane Insurance Market, accessed at http://www.floir.com/siteDocuments/lts_2006.pdf on August 1, 2014.

Frey, W. H., Singer, A. and Park, D. (2007) Resettling New Orleans: The First Full Picture from the Census, Metropolitan Policy Program, Washington, DC, The Brookings Institute.

George, A. L. and Bennett, A. (2005) Case Studies and Theory Development in the Social Sciences, Cambridge, The MIT Press.

Grace, M. F. and Klein, R. W. (2006) After the Storms: Property Insurance Markets in Florida, Center for Risk Management \& Insurance Research Working Paper, Atlanta, Georgia State University.

Grace, M. F. and Klein, R. W. (2009) 'The Perfect Storm: Hurricanes, Insurance, and Regulation', Risk Management and Insurance Review, 12, 81-124.

Grace, M. F., Klein, R. W. and Zhiyong, L. (2005) 'Increased Hurricane Risk and Insurance Market Responses', Journal of Insurance Regulation, 24, 3-23.

Grossi, P. and Kunreuther, H. C. (2005) Catastrophe Modeling: A New Approach to Managing Risk, Springer Science+Media Inc.

Hacker, J. S. (2008) The Great Risk Shift: The New Economic Insecurity and the Decline of the American Dream, Oxford University Press.

Harrington, J. (2005, September 11) 'Rate hikes insure that many will leave Fla.', St Petersburg Times, St. Petersburg, FL, TPT.

Hartman, C. and Squires, G. D. (2006) There is no such thing as a natural disaster: Race, class and Katrina, New York, NY, Routledge. 
Hartwig, R. P. and Wilkinson, C. (2010) 'Hurricane Katrina: the five year anniversary', accessed at http://www.iii.org/sites/default/files/1007Katrina5Anniversary.pdf on June 7, 2014.

Hartwig, R. P. and Wilkinson, C. (2012) 'Residual Market Property Plans: From Markets of Last Resort to Markets of First Choice', accessed at http://www.iii.org/assets/docs/pdf/ResidualMarketWhitePaper-2012.pdf on June 3, 2014.

Holland, G.J., and Webster, P.J. (2007) 'Heightened tropical cyclone activity in the North Atlantic: natural variability or climate trend', Philosophical Transactions of the Royal Society, 365, 2695-2716.

Insurance Information Institute (2012) 'The Insurance Fact Book 2012', accessed at http://iiky.org/documents/Insurance_Factbook_2012.pdf on June 4, 2014.

Insurance Information Institute (2014) 'Catastrophes: U.S.', accessed at http://www.iii.org/factstatistic/catastrophes-us on June 5, 2014.

Insurance Information Institute (2015) 'Residual Markets', accessed at http://www.iii.org/issueupdate/residual-markets on July 28, 2016.

IPCC (2012) Managing the Risks of Extreme Events and Disasters to Advance Climate Change Adaptation, New York, N.Y, Cambridge University Press.

Knight, F. H. (2006 [1921]) Risk, Uncertainty and Profit, Mineola: NY, Dover Publications.

Klein, R. W. (2007) Catastrophe Risk and the Regulation of Property Insurance: A Comparative Analysis of Five States, Working Paper, accessed at http://www.researchgate.net/publication/228345827_Catastrophe_risk_and_the_regulation_of_ property_insurance_A_comparative_analysis_of_five_states on June 3, 2014.

Klein, R. W. (2009) Hurricane Risk and the Property Insurance Markets: An Update and Extension, Working Paper \#2009-10-07, Philadelphia, Wharton Extreme Events Project.

Kunreuther, K. C., Meszaros, J., Hogarth, R. M., and Spranca, M. (1995) ‘Ambiguity and underwriter decision processes', Journal of Economic Behavior and Organization, 26, 337-352. 
Kunreuther, H.C., Pauly, M.V., and McMorrow, S. (2013) Insurance and Behavioral Economics: Improving Decisions in the Most Misunderstood Industry, New York, NY, Cambridge University Press.

Liu, H. F. and Brennan, M. (2008) The Direct Impact of Home Building and Remodeling on the U.S. Economy, accessed at https://www.nahb.org/en/research/housing-economics/specialstudies/archives/the-direct-impact-of-home-building-and-remodeling-on-the-us-economy2008.aspx on 4 August, 2016.

Lowi, T. J. Jr. (1979) The End of Liberalism: The Second Republic of the United States, New York, W.W. Norton.

McCarthy, K. Peterson D.J., Sastry, N. and Pollard, M. (2006) The repopulation of New Orleans after Katrina, Santa Monica, CA, RAND.

Meier, K. J. (1988) The Political Economy of Insurance Regulation: The Case of Insurance, Albany, State University of New York Press.

Melillo, J. M., Richmond, T. and Yohe, G. W. (eds) (2014) Highlights of Climate Change Impacts in the United States: The Third National Climate Assessment. U.S. Global Change Research Program.

Offe, C. (1984) Contradictions of the Welfare State, London, Hutchinson.

Ostrowski, J. (2006, July 25) 'Homeowners RIP insurance package', The Palm Beach Post, Palm Beach, FL, 1D.

Pavalko, E. K. (1989) 'State Timing of Policy Adoption: Workmen’s Compensation in the United States, 1909-1929', American Journal of Sociology, 95, 592-615.

Peltzman, S. (1974) Toward a more general theory of regulation, NBER Working Paper No. 133, Stanford, NBER Working Paper Series.

Poulantzas, N. (1973) Political Power and Social Classes, London, New Left Books. 
Pzeworski, A. (1985) Capitalism and Social Democracy, Cambridge, Cambridge University Press.

Schneiberg, M. and Bartley, T. (2001) 'Regulating American Industries: Markets, Politics, and the Institutional Determinants of Fire Insurance', American Journal of Sociology, 107, 101146.

Schneiberg, M. and Soule, S. A. (2005) 'Institutionalization as Contested Process: The Case of Rate Regulation in American Fire Insurance'. In Davis, G. F., McAdam, D., Scott W. R., and Bald, M. N. (eds) Social Movements and Organization Theory, Cambridge, Cambridge University Press, pp. 122-160.

Simpson, (2006, August 28) 'Blanco: No quick fixes for insurance woes', Associated Press Newswire, APRS.

Stockfisch, J. R. (2007, January 21) 'Lawmakers' Plans Would Cut Premiums', Tampa Tribune, Tampa, FL, KRTTM.

Therborn, G. (1978) What does the ruling class do when it rules?, London, Verso Books.

U.S. Department of Homeland Security (2006) Current housing unit damage estimates:

Hurricane Katrina, Rita, and Wilma, accessed at www.huduser.org/publications/pdf/ GulfCoast_Hsngdmgest.pdf, on 14 June, 2012.

Von Peter, G., von Dahlen, S., and Saxena, S. (2012) Unmitigated disasters? New evidence on the macroeconomic cost of natural catastrophes, BIS Working Papers No. 394, Bank of International Settlements.

Woll, C. (2016) 'Politics in the Interest of Capital: A Not-So Organized Combat', Politics and Society, 44, 373-391.

Zucco, T. (2006, May 24) 'State insurer has a fight on its hands', St. Petersburg Times, St. Petersburg, FL, STPT. 
${ }^{1}$ The federal National Flood Insurance Program writes all insurance against flooding damages. Because I focus on the shifts between private and state-coordinated insurance provision, flooding damages and their federal insurance are bracketed in this paper.

${ }^{2}$ Insurers' stockholders cover voluntary insurance risk and voluntary insurers' creditors in the rare case of insolvency; in the very last instance, State Guarantee Funds cover any policyholders' outstanding claims. State Guarantee Fund Associations pay many of the claims not covered by an insolvent voluntary insurer's assets by assessing the solvent insurers still operating in the state. The owners of surviving insurers bear the administrative costs associated with assessment; they also retain those costs that cannot be shifted to their customers (Barrese and Nelson, 1994).

${ }^{3}$ The large number of possible explanatory factors and the small number of cases causes problems of explanatory under-determination. Relatedly, a comparison of the two cases alone cannot confirm that all of the possible relevant factors have been identified or that the ones that have are indeed necessary or sufficient.

${ }^{4}$ For example, assuming no changes in regulatory restrictions on insurance rate setting or other exogenous market shocks.

${ }^{5}$ Whether the price increases were in fact actuarially justified or not is of no direct relevance to the argument here. What matters is whether market participants, and especially homeowners and lawmakers, regarded them as justifiable or not.

${ }^{6}$ The inherent complexity of catastrophe models, the limited scientific knowledge regarding hurricanes, and a lack of historical data "leave open several possible and competing explanations for the parameters, data, and mathematical models underlying each of the components in a catastrophe model" (Grossi and Kunreuther, 2005, p.70).

${ }^{7}$ Throughout the 2004 and 2005 hurricane seasons and in their immediate aftermath in 2006, neither regulatory nor legislative nor demographic changes significantly altered the original insurer-of-last-resort role of residual insurance providers in either state.

${ }^{8}$ At the time of the 2005 hurricanes, a consumer protection statue that prevented insurers from canceling or nonrenewing homeowners' policies that had been in force for more than three years governed Louisiana's insurance markets, limiting their flexibility in shedding these policies.

${ }^{9}$ Other member groups included the Florida Consumer Action Network, Florida Justice Association, Cyber Citizens for Justice, ACORN, Florida Public Interest Research Group, Coalition of Florida Condominium Association, the Consumer Federation of the Southeast and the Florida AFL-CIO.

${ }^{10}$ Prior approval rating systems require insurers to file their planned rate changes and await approval from regulators before they come into effect. File-and-use systems require insurers to file their rate changes with regulators but can use them immediately after, unless the regulator blocks them within a given time period.

${ }^{11}$ The bill required the Florida insurance regulator to approve ratings that guaranteed insurers a reasonable rate of return commensurate with the risk of covering hurricane losses. Crucially, the bill placed the burden of proof of voluntary rate excess on the regulator. The net effect of this was to make it more difficult for regulators to reject voluntary rate increases.

${ }^{12}$ Between 1972 and 2000, for example, every single Louisiana Insurance Commissioner was indicted for bribery, extortion, or related charges and eventually went to prison. The two largest property insurers in the state, Allstate and State Farm commanded a combined market share of 53\% in the homeowner insurance market in 2005.

${ }^{13}$ This was not the case in Florida where State Farm threatened to leave the market following a regulator rejection of a $47 \%$ price increase in 2009 . The company remained after a compromise was reached with the regulator.

${ }^{14}$ Among other duties, the CFO has administrative oversight over the offices that handle banking and insurance regulation and therefore has great influence over the day-to-day operation of insurance markets.

${ }^{15}$ Only roughly half of New Orleans's population had returned and the African-American percentage of the total state population was down to $58 \%$ from $67 \%$ before Hurricane Katrina (Bohrer, 2007). New Orleans mayor Nagin at one point suggested that a conspiracy kept African-Americans from returning to New Orleans in an effort to change the power structure. He won re-election against a White candidate in 2006.

${ }^{16}$ Some Senate leaders even discussed placing insurance executives under oath when testifying before legislative committees. House speaker Marco Rubio, for example, threatened to subpoena private hurricane forecasting companies in order to establish the soundness and fairness of their pricing methodology. 